\title{
Micron-scale intrashell oxygen isotope variation in cultured planktic foraminifers
}

\author{
Lael Vetter $^{\mathrm{a}, *}$, Reinhard Kozdon ${ }^{\mathrm{b}}$, Claudia I. Mora ${ }^{\mathrm{c}}$, Stephen M. Eggins ${ }^{\mathrm{d}}$, \\ John W. Valley ${ }^{\mathrm{b}}$, Bärbel Hönisch ${ }^{\mathrm{e}}$, Howard J. Spero ${ }^{\mathrm{a}}$ \\ a Department of Geology, University of California Davis, Davis, CA 95616, USA \\ ${ }^{\mathrm{b}}$ WiscSIMS, Department of Geoscience, University of Wisconsin Madison, Madison, WI 53706, USA \\ ${ }^{\mathrm{c}}$ Earth and Environmental Sciences Division, Los Alamos National Laboratory, Los Alamos, NM 87544, USA \\ ${ }^{\mathrm{d}}$ Research School of Earth Sciences, The Australian National University, Canberra, ACT 0200, Australia \\ ${ }^{\mathrm{e}}$ Department of Earth and Environmental Sciences and Lamont-Doherty Earth Observatory of Columbia University, 61 Route $9 \mathrm{~W}$, \\ Palisades, NY 10964, USA
}

Received 4 February 2012; accepted in revised form 30 December 2012; available online 12 January 2013

\begin{abstract}
In this study, we show that the rate of shell precipitation in the extant planktic foraminifer Orbulina universa is sufficiently rapid that $12 \mathrm{~h}$ calcification periods in ${ }^{18} \mathrm{O}$-labeled seawater can be resolved and accurately measured using secondary ion mass spectrometry (SIMS) for in situ $\delta^{18} \mathrm{O}$ analyses. Calcifying $O$. universa held at constant temperature $\left(22^{\circ} \mathrm{C}\right)$ were transferred every $12 \mathrm{~h}$ between ambient seawater $\left(\delta^{18} \mathrm{O}_{\mathrm{w}}=-0.4 \%\right.$ VSMOW) and seawater with enriched barium and $\delta^{18} \mathrm{O}_{\mathrm{w}}=+18.6 \%$ VSMOW, to produce geochemically distinct layers of calcite, separated by calcite precipitated with an ambient geochemical signature. We quantify the position of the Ba-labeled calcite in the shell wall of $O$. universa via laser ablation ICP-MS depth profiling of trace element ratios, and then measure intrashell $\delta^{18} \mathrm{O}_{\text {calcite }}$ in the same shells using SIMS with a $3 \mu \mathrm{m}$ spot and an average precision of $0.6 \%$ o $( \pm 2 \mathrm{SD})$. Measured $\delta^{18} \mathrm{O}_{\text {calcite }}$ values in $O$. universa shell layers are within $\pm 1.1 \%$ of predicted $\delta^{18} \mathrm{O}_{\text {calcite }}$ values. Elemental and oxygen isotope data show that LA-ICP-MS and SIMS measurements can be cross-correlated within the spatial resolution of the two analytical techniques, and that $\delta^{18} \mathrm{O}_{\text {calcite }}$ and elemental tracers appear to be precipitated synchronously with no measurable spatial offsets. These results demonstrate the capability of SIMS to resolve daily growth increments in foraminifer shells, and highlight its potential for paleoceanographic and biomineralization applications on microfossils.
\end{abstract}

(C) 2013 Elsevier Ltd. All rights reserved.

\section{INTRODUCTION}

Analyses of planktic foraminifer shell geochemistry (stable isotope and elemental ratios) are a fundamental component of paleoceanographic and paleoclimatic studies. Such analyses are typically based on multiple pooled foraminifer shells that average the geochemical information in a population and thereby reconstruct mean environmental conditions (e.g., Lea et al., 2000; Weldeab et al., 2007).

\footnotetext{
* Corresponding author.

E-mail address: lvetter@ucdavis.edu (L. Vetter).
}

However, each individual foraminifer in a population locks in seasonal and depth-specific information within its shell chemistry (Killingley et al., 1981; Schiffelbein and Hills, 1984), thereby leaving behind a record of underutilized paleoenvironmental information in multiple contemporaneous shells from single core intervals. Efforts to tap this information archive have yielded insight into phenomena such as the frequency of El Niño-Southern Oscillation events (Koutavas et al., 2006; Leduc et al., 2009), variability in thermocline structure (Slowey and Curry, 1995; Billups and Spero, 1996; Leduc et al., 2009), past sea surface temperature ranges (Stap et al., 2010; Ganssen et al., 2011), and glacial meltwater dynamics (Spero and Williams, 1990). 
The distribution of trace elements within a foraminifer shell can be visualized at micron-scale resolution using an electron microprobe (EPMA) (Eggins et al., 2003; Anand and Elderfield, 2005; Sadekov et al., 2005; Pena et al., 2008; Hathorne et al., 2009), but such analyses are difficult to quantify and provide only a qualitative picture of intrashell geochemical heterogeneity. In contrast, techniques such as laser ablation inductively coupled plasma mass spectrometry (LA-ICP-MS) (Eggins et al., 2003, 2004; Hathorne et al., 2003; Reichart et al., 2003; Pena et al., 2005; Sadekov et al., 2008, 2009, 2010) and secondary ion mass spectrometry (SIMS) (Allison and Austin, 2003; Bice et al., 2005; Kunioka et al., 2006; Curry and Marchitto, 2008) have provided researchers with the opportunity to quantify shell geochemical heterogeneity at micron spatial scales, which reflects calcification over timescales of days. Although significant elemental variability has been documented in foraminiferal shell calcite, far less is known about $\delta^{18} \mathrm{O}$ heterogeneity in foraminifer shells at the micron scale.

Oxygen isotope analyses using SIMS with a $\mathrm{Cs}^{+}$primary beam have been used to address questions about climate variability (Orland et al., 2009, 2012), mineral formation, crystallization temperatures, and mantle dynamics (Valley, 2003). However, the use of SIMS for in situ $\delta^{18} \mathrm{O}$ measurements on biologically precipitated calcite is still in its infancy. For instance, micron-scale $\delta^{18} \mathrm{O}_{\text {calcite }}$ (hereafter $\delta^{18} \mathrm{O}_{\mathrm{c}}$ ) measurements on fish otoliths (Weidel et al., 2007; Shirai et al., 2010) and mollusk nacre (Olson et al., 2012) have been used to reconstruct life processes and temperature during biomineralization. In a landmark study, Rollion-Bard et al. (2008) utilized a $15 \mu \mathrm{m}$ diameter SIMS spot to document intrashell oxygen isotope variability in live-collected and cultured specimens of a long-lived $(\sim 2$ years) benthic foraminifer, and demonstrated offsets in $\delta^{18} \mathrm{O}_{\mathrm{c}}$ that were thought to reflect primary and secondary calcification and a $6{ }^{\circ} \mathrm{C}$ temperature range during shell formation. Kozdon et al. (2009) applied this technique on Recent high latitude fossil foraminifera from the North Atlantic, and reported intrashell $\delta^{18} \mathrm{O}_{\mathrm{c}}$ heterogeneity of up to $3 \%$ that was interpreted to result from changes in habitat depth during ontogeny. More recently, Kozdon et al. (2011) demonstrated that in situ spot measurements targeting unaltered subdomains of calcite within the shell walls of Paleocene-Eocene thermal maximum planktic foraminifers yield unaltered $\delta^{18} \mathrm{O}_{\mathrm{c}}$ values that imply paleo sea surface temperatures $4-8{ }^{\circ} \mathrm{C}$ warmer than data from wholeshell analyses. These studies highlight the value of conducting micron-scale, in situ, intrashell oxygen isotope analyses on fossil foraminifera to extract novel paleoenvironmental information.

The extant planktic foraminifer Orbulina universa is an ideal species for studying intrashell oxygen isotope heterogeneity in laboratory experiments for several reasons. First, the life history, ontogenetic development and geochemistry of $O$. universa is well-characterized (e.g., Spero, 1988; Spero and Williams, 1988; Lea and Spero, 1992; Spero et al., 1997; Bemis et al., 1998; Hönisch et al., 2011). Second, this species secretes a spherical adult chamber near the end of its life cycle that calcifies continuously over the course of $\sim 3-7$ days (Spero, 1988), and it is relatively easy to maintain in the laboratory (e.g., Caron et al., 1987). Third, a well-constrained species-specific calibration of the $\delta^{18} \mathrm{O}_{\mathrm{c}}$-temperature relationship for $O$. universa has been published using laboratory-grown specimens (Bemis et al., 1998), thereby allowing us to predict the $\delta^{18} \mathrm{O}$ value of calcite precipitated in water of known $\delta^{18} \mathrm{O}_{\text {water }}$ (hereafter $\delta^{18} \mathrm{O}_{\mathrm{w}}$ ) and temperature with a $2 \sigma$ precision of $\pm 0.1 \%$.

In this study, we present the results of laboratory experiments in which $O$. universa was grown for $12 \mathrm{~h}$ periods in seawater with altered $\delta^{18} \mathrm{O}_{\mathrm{w}}$ and a secondary elemental $\mathrm{Ba}$ spike in order to produce time-resolved bands of shell calcite with predictable geochemistries. Bands of calcite precipitated in ambient and modified seawater were measured using both SIMS $\left(\delta^{18} \mathrm{O}_{\mathrm{c}}\right)$ and LA-ICP-MS $(\mathrm{Ba} / \mathrm{Ca})$. We demonstrate that SIMS analyses using a $3 \mu \mathrm{m}$ beam spot diameter can resolve micron-scale $\delta^{18} \mathrm{O}_{\mathrm{c}}$ variability in shells from laboratory grown $O$. universa. Such analytical capabilities suggest that it may be possible to reconstruct changes in past environmental conditions, such as temperature and salinity, with daily resolution.

\section{MATERIALS AND METHODS}

\subsection{Laboratory culture experiments}

Juvenile, pre-sphere $O$. universa were hand-collected by scuba divers in the Southern California Bight during July and August of 2008 and cultured at the Wrigley Marine Science Center, Santa Catalina Island, California. We also collected ambient seawater $2 \mathrm{~km}$ offshore for use in culture experiments, and filtered it through $0.8 \mu \mathrm{m}$ nitrate cellulose filters. Ambient seawater had average salinity $=33.3 \%$, $\mathrm{pH}$ 8.04 (total scale), alkalinity $=2250 \mu \mathrm{mol} \mathrm{kg} \mathrm{kg}^{-1}$, and $\delta^{18} \mathrm{O}_{\mathrm{w}}=-0.40 \% \pm 0.03 \%$ (VSMOW; $\pm 2 \mathrm{SE}, n=12$ ). Following collection, individual specimens were transferred into $120 \mathrm{ml}$ glass jars containing filtered ambient seawater, and maintained at $22^{\circ} \mathrm{C}\left( \pm 0.2^{\circ} \mathrm{C}\right)$ in water baths.

All $O$. universa specimens were grown under fluorescent lamps with an intensity of $299-406 \mu \mathrm{mol}$ photons $\mathrm{m}^{-2} \mathrm{~s}^{-1}$ on a $12 \mathrm{~h}$ light: $12 \mathrm{~h}$ dark cycle. Each $O$. universa was fed a 1-day-old Artemia nauplius every other day, following previously established methods of planktic foraminifer culturing (Bemis et al., 1998; Lea et al., 1999; Russell et al., 2004). Juvenile, trochospiral stage $O$. universa were maintained in ambient seawater until they precipitated a spherical adult chamber, which thickens continuously over a 3-7 day period (Spero, 1988). All experiments were conducted during this sphere-thickening phase of growth; the thin $(\sim 1 \mu \mathrm{m})$ juvenile trochospiral shell was not used for subsequent analyses.

One group of foraminifers was cultured continuously in synthetic seawater until gametogenesis to produce shells expected to have a constant geochemistry. Batches of synthetic seawater were prepared by adding salts to $18.2 \mathrm{M} \Omega$ nanopure water to match the concentrations of major cations and anions in seawater (Table 1). Alkalinity was controlled by the addition of $\mathrm{NaHCO}_{3}$ and followed by titration to the $\mathrm{pH}$ of ambient seawater via addition of $\mathrm{HCl}$ using a Metrohm 785 Titrino autotitrator. Synthetic and ambient filtered seawater were mixed together in a 
Table 1

Synthetic seawater recipe for culture water.

\begin{tabular}{ll}
\hline Salt & Amount added $(\mathrm{g})$ \\
\hline $\mathrm{NaCl}$ & 45.98 \\
$\mathrm{Na}_{2} \mathrm{SO}_{4}$ & 7.692 \\
$\mathrm{KCl}$ & 1.46 \\
$\mathrm{NaHCO}$ & \\
$\mathrm{B}(\mathrm{OH})_{3}$ & 0.3416 \\
$\mathrm{MgCl}_{2} \cdot 6 \mathrm{H}_{2} \mathrm{O}$ & 0.0485 \\
$\mathrm{CaCl}_{2} \cdot 2 \mathrm{H}_{2} \mathrm{O}$ & 20.58 \\
$\mathrm{SrCl}_{2} \cdot 6 \mathrm{H}_{2} \mathrm{O}$ & 2.8975 \\
$\mathrm{BaCl}_{2}$ & 0.0464 \\
\hline
\end{tabular}

${ }^{a}$ Amount added to 1 liter of $18.2 \mathrm{M}$ milliQ water.

${ }^{\mathrm{b}}$ See Section 2.1 text for description of concentrated Ba spike preparation.

1:3 ratio to demonstrate that $O$. universa would calcify in an artificial seawater solution. In this seawater mixture, $\delta^{18} \mathrm{O}_{\mathrm{w}}=-1.54 \%( \pm 0.07 \%, \pm 2 \mathrm{SE}, n=3)$ and calculated $[\mathrm{Ba}]=44 \mathrm{nmol} \mathrm{kg}^{-1}$.

A second set of experiments was conducted in which individual $O$. universa precipitated shell calcite while being transferred back and forth between ambient seawater and seawater with modified $\mathrm{Ba} / \mathrm{Ca}$ and $\delta^{18} \mathrm{O}_{\mathrm{w}}$ chemistry at $12 \mathrm{~h}$ intervals. The relationship between seawater and shell $\mathrm{Ba} / \mathrm{Ca}$ was previously established for $O$. universa in laboratory experiments (Lea and Spero, 1992, 1994); Ba/Ca $\mathrm{Calcite}$ is a direct function of $\mathrm{Ba} / \mathrm{Ca}_{\text {seawater }}$, independent of temperature, salinity, alkalinity, and other geochemical parameters (Hönisch et al., 2011). We use elevated [Ba] to label foraminifer calcite and visualize calcification at the sub-micron-scale via LA-ICP-MS (Spero et al., 2012). Seawater was doubly labeled by addition of $\mathrm{H}_{2} \mathrm{O}$ with $1.5 \%{ }^{18} \mathrm{O}$ (final $\left.\delta^{18} \mathrm{O}_{\mathrm{w}}=+18.65 \pm 0.05 \%, 2 \mathrm{SE}, n=3\right)$ and concentrated $\mathrm{BaCl}_{2}$ spike solution $\left([\mathrm{Ba}]=720 \mu \mathrm{mol} \mathrm{kg}{ }^{-1}\right.$, calculated final

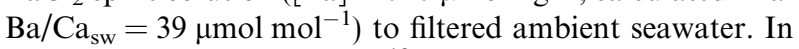
comparison, ambient $\delta^{18} \mathrm{O}_{\mathrm{w}}=-0.40 \%$ and $\mathrm{Ba} /$ $\mathrm{Ca}_{\mathrm{sw}}=4.4 \mu \mathrm{mol} \mathrm{mol}^{-1}$.

Individual $O$. universa were transferred via pipette into the $\mathrm{Ba}$ - and ${ }^{18} \mathrm{O}$-enriched seawater at the start of a $12 \mathrm{~h}$ light period, and maintained at $22^{\circ} \mathrm{C}$. These individuals were subsequently transferred back into ambient seawater at the start of the $12 \mathrm{~h}$ dark period. This procedure was repeated to produce shells expected to have alternating calcite layers with predictable $\delta^{18} \mathrm{O}_{\mathrm{c}}$ and $\mathrm{Ba}$ composition. In a parallel experiment, we grew $O$. univers $a$ in doubly labeled seawater during the $12 \mathrm{~h}$ dark periods, followed by a transfer into ambient seawater during the $12 \mathrm{~h}$ light periods. To minimize contamination, all individual $O$. universa were first transferred into an intermediate jar containing the same seawater (labeled or ambient) as the destination jar before final transfer into labeled or ambient seawater for the $12 \mathrm{~h}$ calcification interval.

Following two full cycles of transfers between labeled and ambient seawater, each specimen was maintained in filtered seawater at $22{ }^{\circ} \mathrm{C}$ until it had undergone gametogenesis, at which time the shell was nearly devoid of cytoplasm. After gametogenesis, experimental shells were rinsed in deionized water and archived individually for later analysis.
Prior to geochemical analyses, shells of individual $O$. universa spherical adults were manually cracked into several fragments using a disposable scalpel and isolated and cleaned for $10 \mathrm{~min}$ in a $1: 1$ solution of $30 \% \mathrm{H}_{2} \mathrm{O}_{2}$ and $0.1 \mathrm{~N} \mathrm{NaOH}$ at $65^{\circ} \mathrm{C}$ to remove residual organic matter. Shells were then rinsed in deionized water, sonicated for $10-15 \mathrm{~s}$ in reagent grade methanol to remove any additional adherent material, and rinsed two additional times in deionized water.

Water samples were collected for analysis both before and after live culture experiments. The $\delta^{18} \mathrm{O}_{\mathrm{w}}$ values of these samples were determined at the Stable Isotope Laboratory, Department of Geology, University of California, Davis, on a Finnigan MAT 251 dual inlet mass spectrometer using a $\mathrm{CO}_{2}$ water equilibrator. The reproducibility of replicate water analyses was typically $\pm 0.06 \%$ ( $\pm 2 \mathrm{SD}$ ). We compute the $\mathrm{Ba} / \mathrm{Ca}$ ratio of synthetic seawater based on the recorded volume of concentrated $\mathrm{BaCl}_{2}$ solution $\left(720 \mu \mathrm{mol} \mathrm{kg}{ }^{-1}\right)$ added to experimental culture water (Table 1 ), and predict the $\mathrm{Ba} / \mathrm{Ca}_{\text {calcite }}$ of specimens cultured in synthetic seawater using the relationship of Hönisch et al. (2011).

\subsection{Intrashell $\mathrm{Ba} / \mathrm{Ca}$ analyses with $\mathrm{LA}-\mathrm{ICP}-\mathrm{MS}$}

One fragment of each $O$. universa specimen was analyzed for its trace element composition by LA-ICP-MS. Trace element concentrations were measured using a pulsed 193 nm Lambda Physik ArF Excimer laser (25 ns pulse width) with dual-volume ANU Helex sample chamber, coupled to an Agilent 7500s quadrupole ICP-MS at the Australian National University (ANU), Canberra, ACT, Australia. Shell fragments were mounted on double-stick carbon tape and ablated in depth profile from shell interior to exterior at a rate of $4 \mathrm{~Hz}$, using a $37 \mu \mathrm{m}$ spot diameter and laser fluence of $\sim 3-4 \mathrm{~J} \mathrm{~cm}^{-2}$. Each laser pulse ablates $\sim 0.1 \mu \mathrm{m}$, based on validation experiments of laser energy with ablation of spar calcite and subsequent examination of ablated pits using SEM images (Eggins et al., 2004). The sample holding chamber has a mean ablated particulate residence time of $\sim 0.35 \mathrm{~s}$, enabling rapid collection of depth profile data at sub-micron resolution. Each $O$. univer$s a$ shell fragment was ablated to give a depth profile, parallel to the direction of shell growth, in three different locations on the same shell. Shell fragments were ablated from the inner shell surface to outer shell surface to avoid mixing of growth layers by ablating the uneven topography on the outer, porous surface of the shell (Eggins et al., 2004).

We collected data for ${ }^{24} \mathrm{Mg},{ }^{25} \mathrm{Mg},{ }^{27} \mathrm{Al},{ }^{43} \mathrm{Ca},{ }^{44} \mathrm{Ca}$, ${ }^{55} \mathrm{Mn},{ }^{88} \mathrm{Sr}$, and ${ }^{138} \mathrm{Ba}$, with an average of $30 \mathrm{~ms}$ dwell time on each mass. Internal standardization within analyses was performed using ${ }^{43} \mathrm{Ca}$. Counts per second on ${ }^{27} \mathrm{Al}$ and ${ }^{55} \mathrm{Mn}$ were monitored to identify phases that were contaminantrich or contained material from the sample mount, as per Pena et al. (2008), though counts on these elements remained relatively low because live cultured shells do not have the same potential for contamination with sediment. Data reduction methods consisted of initial screening for outliers, followed by subtracting measured background 
intensities, measured with the laser turned off. An identical ablation protocol for NIST 610 glass bracketed each group of 15-20 sample analyses. To quantify elemental ratios in samples, measured elemental intensities on samples were ratioed to measured elemental intensities from bracketing analyses of NIST 610 glass (GeoReM Database, 2009) in the same analytical session. A full description of data reduction methods can be found in Eggins et al. (2003).

We use measured intrashell $\mathrm{Ba} / \mathrm{Ca}$ to delineate regions of calcite precipitated in ambient and labeled seawater. Instantaneous changes in seawater cation chemistry are recorded in $O$. universa shell calcite within $<1 \mu \mathrm{m}$, as demonstrated by recent nanoSIMS profiles across cultured $O$. universa shells (Gagnon et al., 2012). When measured by LA-ICP-MS depth profiling, the same trace element transitions are expressed across $1-2 \mu \mathrm{m}$ of shell calcite in the direction of growth (Spero et al., 2012). Measurements across bands of labeled and ambient calcite thus consist of two zones: a zone where the labeled or ambient shell chemistry is fully resolved by the LA-ICP-MS technique, and an analytical mixing zone where analyses mass-average material from portions of the shell with different geochemistries (Fig. 1). For intrashell Ba/Ca measured by LA-ICPMS depth profiling, we use the initial rise in shell $\mathrm{Ba}$ (or decrease in $\mathrm{Ba}$ ) to identify the start of a $12 \mathrm{~h}$ labeling period between ambient and ${ }^{18} \mathrm{O}$ - and $\mathrm{Ba}$-enriched water (or vice versa) (Fig. 1).

\subsection{Intrashell in situ $\delta^{18} \mathrm{O}$ SIMS analyses}

Orbulina universa specimens that displayed the most clearly defined bands of labeled and ambient $\mathrm{Ba} / \mathrm{Ca}$ were chosen for SIMS analyses. A second fragment of each shell was mounted in Buehler EpoxiCure resin with low vapor pressure in a $25 \mathrm{~mm}$ epoxy round and polished. Samples

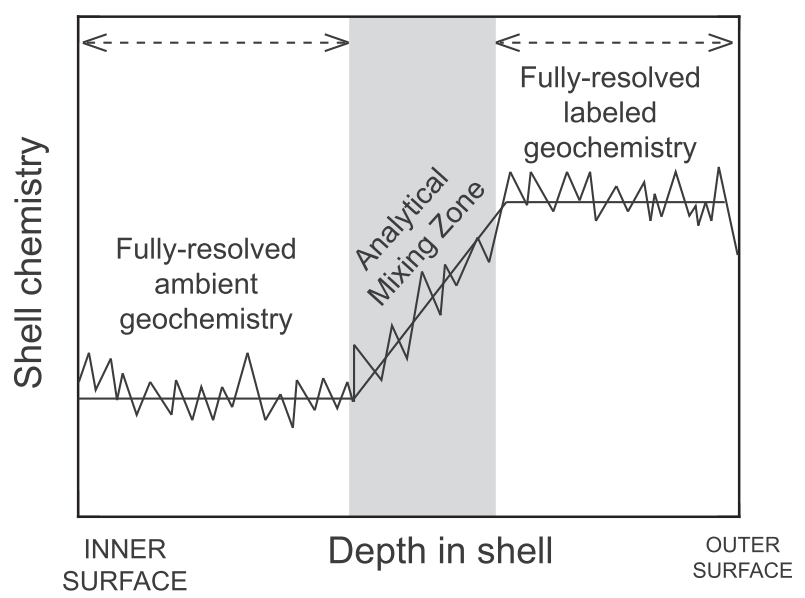

Fig. 1. Idealized LA-ICP-MS depth profile showing measured shell chemistry across an instantaneous change in seawater chemistry. Depending on the spatial resolution of the analytical technique (LA-ICP-MS or SIMS), some regions of the shell are sampled such that ambient or labeled values are fully resolved in shell calcite. In other regions, both ambient and labeled calcite are sampled during analyses, and intermediate values are expressed in an analytical mixing zone. were placed within $5 \mathrm{~mm}$ of the center of the round with at least two grains of the WiscSIMS calcite standard UWC-3 $\quad\left(\delta^{18} \mathrm{O}=+12.49 \%\right.$ VSMOW, Kozdon et al., 2009), ground to approximately $50 \mu \mathrm{m}$ depth to expose shell fragments in cross section to the growth direction, polished, and gold coated. Secondary electron images of individual $O$. universa shell fragments were generated using a Cameca SX-100 electron microprobe in scanning electron microscope (SEM) mode to assess sample exposure quality and cross-section geometry prior to SIMS analysis.

Samples were analyzed with a Cameca ims-1280 ion microprobe (SIMS) at the WiscSIMS Laboratory, Department of Geoscience, University of Wisconsin-Madison using a ${ }^{133} \mathrm{Cs}^{+}$primary ion beam with an intensity of 15 $18 \mathrm{pA}$ and a beam spot size of $3 \mu \mathrm{m}$. Secondary ${ }^{18} \mathrm{O}^{-}$and ${ }^{16} \mathrm{O}^{-}$ions were detected simultaneously using a Faraday cup $\left({ }^{16} \mathrm{O}\right)$ and an electron multiplier $\left({ }^{18} \mathrm{O}\right)$ with a typical count rate of $2.5 \times 10^{7} \mathrm{cps}$ for ${ }^{16} \mathrm{O}^{-}$. The total analytical time per spot was $7 \mathrm{~min}$ including presputtering $(2 \mathrm{~min}$ ). The operating conditions of the SIMS during analyses followed those used in previous studies (Page et al., 2007; Kozdon et al., 2009). Sample data collection was bracketed by 4-6 consecutive analyses of $\delta^{18} \mathrm{O}$ in a UWC-3 grain mounted in the center of the sample mount, following each group of 8-14 different spot measurements of foraminiferal calcite $\delta^{18} \mathrm{O}$. We standardized our measurements using these bracketing standard analyses to determine instrumental mass fractionation corrections for each set of foraminiferal calcite measurements, and converted oxygen isotope values from VSMOW to VPDB using the conversion of Coplen et al. (1983). The reproducibility of $\delta^{18} \mathrm{O}$ values of individual spot analyses on the UWC-3 calcite standard grain bracketing the samples ranged from $0.3 \%$ to $1.1 \%$ o $( \pm 2$ $\mathrm{SD}, 3 \mu \mathrm{m}$ spots) and is assigned as the uncertainty range of individual sample measurements. We performed a total of 106 measurements, including 45 spots for bracketing standards. Individual analyses on foraminifer shells that yielded less than $85 \%$ of the bracketing counts per second (cps) measured on the UWC-3 standard grain were discarded. Following $\delta^{18} \mathrm{O}$ analyses by SIMS, analysis spots were imaged using a Hitachi S-3400N SEM. We present all data (Table 2) except from spots that overlapped with epoxy, cracks, or other deformities, and spots in areas of high porosity within the shell wall ( 7 of 106 spots discarded; spots marked * in Figs. 2C and 3C, D). The complete data set, including bracketing standard analyses, is listed in Supplementary data Table S1.

For each sample, we generated transects parallel to the direction of growth across the exposed shell cross-section with a $6 \mu \mathrm{m}$ spacing of the analysis pits. Generally, we repeated this analytical transect perpendicular to growth bands a total of three times in parallel tracks, so that spot centers in each row of the traverse were offset by $2 \mu \mathrm{m}$ relative to the spot analyses in the adjacent traverse. The effective spatial resolution of all analysis pits together thus approaches $2 \mu \mathrm{m}$. On one specimen (C8-483; Fig. 3A-E) we repeated this sampling technique on the opposite side of the shell to investigate the reproducibility of transects in different regions of the shell (Table 2). We report oxygen isotope values versus the distance from the inner shell wall 
Table 2

Individual $\delta^{18} \mathrm{O}_{\mathrm{c}}$ SIMS spot analyses measured at WiscSIMS, precision, and distance from inner shell wall.

\begin{tabular}{|c|c|c|c|c|}
\hline $\begin{array}{l}\text { Specimen and } \\
\text { pit \# }\end{array}$ & $\begin{array}{l}\text { WiscSIMS lab analysis identifier } \\
\text { February } 22,2010\end{array}$ & $\begin{array}{l}\text { Distance from inner shell } \\
\text { surface }(\mu \mathrm{m})\end{array}$ & $\begin{array}{l}\delta^{18} \mathrm{O}_{\mathrm{c}} \% \\
\mathrm{VPDB}\end{array}$ & $\begin{array}{l} \pm 2 \mathrm{SD} \\
(\%)\end{array}$ \\
\hline \multicolumn{5}{|l|}{ Specimen 498} \\
\hline $\mathrm{a}$ & @ 82 & 3.6 & -2.9 & 1.1 \\
\hline f & @83 & 4.0 & -3.0 & 1.1 \\
\hline $\mathrm{d}$ & @87 & 5.1 & -3.4 & 1.1 \\
\hline $\mathrm{b}$ & @) 90 & 6.8 & -3.6 & 1.1 \\
\hline g & @84 & 8.5 & -3.3 & 1.1 \\
\hline $\mathrm{e}$ & @ 88 & 11.1 & -2.5 & 1.1 \\
\hline $\mathrm{c}$ & @91 & 12.7 & -3.3 & 1.1 \\
\hline $\mathrm{h}$ & @85 & 13.8 & -3.7 & 1.1 \\
\hline $\mathrm{i}$ & @86 & 20.2 & -2.6 & 1.1 \\
\hline
\end{tabular}

Specimen 483 Transect 1

$\begin{array}{ll}\mathrm{k} & @ 21 \\ \mathrm{l} & @ 22 \\ \mathrm{~m} & @ 23 \\ \mathrm{a} & @ 24 \\ \mathrm{e} & @ 35 \\ \mathrm{~h} & @ 36 \\ \mathrm{~b} & @ 25 \\ \mathrm{f} & @ 30 \\ \mathrm{c} & @ 26 \\ \mathrm{i} & @ 37 \\ \mathrm{~g} & @ 29 \\ \mathrm{~d} & @ 27 \\ \mathrm{j} & @ 38\end{array}$

\section{7}

3.5

3.7

4.9

6.9

9.1

9.3

12.8

15.0

15.0

18.6

20.6

20.9

Specimen 483 Transect 2

$\begin{array}{ll}\text { n } & @ 53 \\ \mathrm{~s} & @ 42 \\ \mathrm{q} & @ 49 \\ \mathrm{o} & @ 52 \\ \mathrm{r} & @ 50 \\ \mathrm{r} & @ 40 \\ \mathrm{p} & @ 51 \\ \mathrm{u} & @ 39 \\ \mathrm{v} & @ 55\end{array}$

Specimen 495

$$
\text { b }
$$

i

c

j

j

k

d

f

$\mathrm{f}$
$\mathrm{g}$
$\mathrm{h}$

Specimen 728

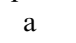

$\mathrm{g}$

$\mathrm{k}$
$\mathrm{b}$

$\mathrm{b}$
$\mathrm{h}$

$\mathrm{h}$
$\mathrm{l}$
$\mathrm{c}$

i

m

d

j

e
@. 53

a) 42

a,52

(a) 50

a) 40

(a)39

@ 55

(a)69

(a)64

(a)68

(a)63

@.70

(a)62

(a)67

(a)66

(a)65

(a)61

(a)60

@100

(a)105

(a)113

(a)101

@106

(a) 114

(a)102

(a)107

(a) 115

(a) 103

(a)108

(a)104

(a)116
4.4

7.1

11.0

15.4

16.6

18.6

21.3

22.4

27.9

2.1

3.3

6.4

6.8

7.9

10.1

10.4

14.2

17.7

16.0

20.1

2.5

4.3

5.9

8.0

10.3

11.6

13.2

15.6

17.8

19.1

22.0

24.9

25.5 $\begin{array}{ll}11.2 & 0.5\end{array}$

$\begin{array}{ll}5.5 & 0.5\end{array}$

$\begin{array}{ll}11.8 & 0.5\end{array}$

$\begin{array}{ll}2.5 & 0.5\end{array}$

$\begin{array}{ll}6.1 & 0.7\end{array}$

$\begin{array}{ll}13.5 & 0.7\end{array}$

$\begin{array}{ll}13.8 & 0.5\end{array}$

$\begin{array}{ll}13.9 & 0.5\end{array}$

$16.1 \quad 0.5$

$\begin{array}{ll}15.6 & 0.7\end{array}$

$\begin{array}{ll}-0.1 & 0.5\end{array}$

$\begin{array}{ll}-1.5 & 0.5\end{array}$

$\begin{array}{ll}-2.1 & 0.7\end{array}$

$\begin{array}{ll}13.2 & 0.7\end{array}$

$\begin{array}{ll}4.6 & 0.7\end{array}$

$\begin{array}{ll}7.2 & 0.7\end{array}$

$\begin{array}{ll}16.4 & 0.7\end{array}$

$\begin{array}{ll}11.5 & 0.7\end{array}$

$\begin{array}{ll}5.6 & 0.7\end{array}$

$\begin{array}{ll}-2.8 & 0.7\end{array}$

$\begin{array}{ll}-1.7 & 0.7\end{array}$

$\begin{array}{ll}-2.2 & 0.7\end{array}$

$9.1 \quad 0.6$

$\begin{array}{ll}8.2 & 0.6\end{array}$

$\begin{array}{ll}5.5 & 0.6\end{array}$

$2.5 \quad 0.6$

$13.9 \quad 0.6$

$15.6 \quad 0.6$

$17.5 \quad 0.6$

$\begin{array}{ll}1.2 & 0.6\end{array}$

$\begin{array}{ll}-2.0 & 0.6\end{array}$

$\begin{array}{ll}-1.7 & 0.6\end{array}$

$\begin{array}{ll}-1.3 & 0.6\end{array}$

$\begin{array}{ll}3.2 & 0.3\end{array}$

$\begin{array}{ll}5.1 & 0.3\end{array}$

$\begin{array}{ll}2.6 & 0.5\end{array}$

$\begin{array}{ll}-2.4 & 0.3\end{array}$

$5.4 \quad 0.3$

$\begin{array}{ll}11.2 & 0.5\end{array}$

$\begin{array}{rr}8.3 & 0.3\end{array}$

$\begin{array}{ll}-1.8 & 0.3\end{array}$

$\begin{array}{ll}13.0 & 0.5\end{array}$

$15.5 \quad 0.3$

$\begin{array}{ll}-2.5 & 0.3\end{array}$

$\begin{array}{ll}-2.6 & 0.3\end{array}$

$\begin{array}{ll}-2.6 & 0.5\end{array}$ 
as measured to the center of each analysis spot (Figs. 2B, $3 \mathrm{~B}, \mathrm{G}$, and $4 \mathrm{~B})$. Spot analyses of $\delta^{18} \mathrm{O}$ reflect an average value from the entire $3 \mu \mathrm{m}$ spot sampled by the SIMS beam. Some spot analyses are spatially positioned such that they fully resolve $\delta^{18} \mathrm{O}_{\mathrm{c}}$ in shell chemistry for either ambient or spiked seawater. Other SIMS spots sample areas that overlap adjacent bands of shell calcite precipitated in seawaters with different $\delta^{18} \mathrm{O}_{\mathrm{w}}$ values, and yield values of $\delta^{18} \mathrm{O}_{\mathrm{c}}$ intermediate between the two band compositions.

We utilize the empirical temperature vs. shell $\delta^{18} \mathrm{O}$ relationship of Bemis et al. (1998) for calcification in high-light intensity to predict $O$. universa shell $\delta^{18} \mathrm{O}$ :

$T^{\circ} \mathrm{C}=14.9-4.80 *\left(\delta^{18} \mathrm{O}_{\mathrm{c}}-\left(\delta^{18} \mathrm{O}_{\mathrm{w}}-0.27\right)\right)$

with $\delta^{18} \mathrm{O}_{\mathrm{c}}$ measured with respect to VPDB and $\delta^{18} \mathrm{O}_{\mathrm{w}}$ measured with respect to VSMOW, using the convention of Epstein et al. (1953). The $\delta^{18} \mathrm{O}_{\mathrm{w}}$ values of ambient, synthetic, and spiked seawater samples were measured by IRMS (Section 2.1) and used to compute predicted values of $\delta^{18} \mathrm{O}_{\mathrm{c}}$ for calcite precipitated in each solution (Table 3).

\section{RESULTS}

Specimen C8-498 was cultured continuously in a synthetic seawater mixture during sphere calcification, and records homogeneous intrashell $\mathrm{Ba} / \mathrm{Ca}$ with a mean ratio of $0.7 \mu \mathrm{mol} \mathrm{mol}^{-1}$ (Fig. 2A), with external spot-to-spot reproducibility of $0.03 \mu \mathrm{mol} \mathrm{mol}^{-1}( \pm 2 \mathrm{SE}, n=3)$ for repeat depth profiles through the same shell. This is in excellent agreement with the predicted ratio of $0.7 \mu \mathrm{mol} \mathrm{mol}^{-1}$, based on the relationship of Hönisch et al. (2011) and a calculated $\mathrm{Ba} / \mathrm{Ca}_{\mathrm{sw}}=4.4 \mu \mathrm{mol} \mathrm{mol}^{-1}$ of experimental seawater. Multiple intrashell SIMS analyses on this specimen also demonstrate shell $\delta^{18} \mathrm{O}_{\mathrm{c}}$ is homogeneous, with a mean value of $-3.1 \pm 0.4 \%$ o $( \pm 2 \mathrm{SE}, n=9$; VPDB $)$. These $\delta^{18} \mathrm{O}_{\mathrm{c}}$ data are in excellent agreement with the predicted value of $-3.3 \%$ VPDB, based on Eq. (1) and a measured $\delta^{18} \mathrm{O}_{\mathrm{w}}$ value of $-1.5 \%$ (VSMOW). The measured values of all nine individual spot analyses on specimen C8-498 are within $2 \mathrm{SD}( \pm 1.1 \%)$ of the predicted $\delta^{18} \mathrm{O}_{\mathrm{c}}$ value for this SIMS analytical session (Fig. 2B).

Fig. 3 shows data from two $O$. universa specimens (C8-483 and C8-495) that calcified in labeled seawater during the day and ambient seawater during the night. Measured intrashell $\mathrm{Ba} / \mathrm{Ca}$ delineates the spatial position of bands precipitated in ambient and labeled seawater, with analytical mixing zones of $1-2 \mu \mathrm{m}$ between zones of fullyresolved shell chemistry (Fig. 3A and F). Most of the measured $\delta^{18} \mathrm{O}_{\mathrm{c}}$ data within the labeled calcite day bands (Fig. $3 \mathrm{~B}$ and $\mathrm{G}$ ) yield intermediate values that range from $4.6 \%$ to $16.4 \%$ (VPDB) for C $8-483$ (spots b, e, f, h, i, k, r, and s, Fig. 3B) and from $9.1 \%$ to $15.6 \%$ for C8-495 (spots a, b, and k; Fig. 3G). However, three measurements (spots c and o on C8-483; spot d on C8-495; Fig. 3) approach the predicted $\delta^{18} \mathrm{O}_{\mathrm{c}}$ value of $+16.9 \%$ (VPDB) for calcification in labeled seawater within $\pm 1.1 \%$, which is the most conservative precision achieved for any of our analytical sessions. Within the bands of ambient calcite, eleven measured $\delta^{18} \mathrm{O}_{c}$ values are also intermediate, ranging from $-0.1 \%$ to $13.2 \%$ on $\mathrm{C} 8-483$ (spots a, g, $1, \mathrm{~m}, \mathrm{n}, \mathrm{q}$, and $\mathrm{t}$ ) and $1.2 \%$ to $8.2 \%$
VPDB on C8-495 (spots c, e, i, and j). Eight spot analyses are within $\pm 1.1 \%$ of the predicted $\delta^{18} \mathrm{O}_{\mathrm{c}}$ value for ambient calcification, $-2.1 \%$ VPDB (spots $\mathrm{d}, \mathrm{j}, \mathrm{p}, \mathrm{u}$, and $\mathrm{v}$ on C8-483; spots f, $g$, and $h$ on C8-495).

Fig. $4 \mathrm{~A}-\mathrm{C}$ shows intrashell $\mathrm{Ba} / \mathrm{Ca}$ and $\delta^{18} \mathrm{O}_{\mathrm{c}}$ for a specimen that grew in a reverse labeling experiment that labeled seawater during the $12 \mathrm{~h}$ dark calcification periods. Most measured $\delta^{18} \mathrm{O}_{\mathrm{c}}$ values inside of labeled night-calcite bands are intermediate between predicted ambient and labeled calcite, with values ranging between $5.4 \%$ and $15.5 \%$ VPDB (spots h, m, and d; Fig. 4B). One analysis pit in a band of labeled night-calcite (spot b) has an ambient $\delta^{18} \mathrm{O}_{\mathrm{c}}$ value of $-2.4 \%$ (Fig. 4B). In bands of calcite precipitated in ambient seawater, $\delta^{18} \mathrm{O}_{\mathrm{c}}$ values of individual spot analyses range from $-2.6 \%$ to $+11.2 \%$ ( $n=7$; Fig. $4 \mathrm{~B})$. Four of these $\delta^{18} \mathrm{O}_{\mathrm{c}}$ analyses are within $\sim 1.1 \%$ of the predicted ambient value of $-2.1 \%$ (spots e, f, i, and j; Table 2; Fig. 4B), and three of these spots yield measured $\delta^{18} \mathrm{O}_{\mathrm{c}}$ values that are intermediate between values predicted for ambient and labeled calcite (spots c, k, and 1; Table 2; Fig. 4B). Two analyses with intermediate $\delta^{18} \mathrm{O}_{\mathrm{c}}$ values of $3.2 \%$ and $5.1 \%$ were placed in the inner calcite where multiple thin bands of labeled and ambient calcite occur (spots a and g; Fig. 4B).

\section{DISCUSSION}

Emiliani (1955) first demonstrated the use of foraminiferal $\delta^{18} \mathrm{O}_{\mathrm{c}}$ to reconstruct past ocean temperatures from the marine sedimentary fossil record. Since that time, most paleoceanographic studies have focused on obtaining a mean environmental signal from a foraminifera assemblage through the analysis of multiple shells per sample. However, there is extensive evidence that some planktic foraminifers migrate vertically through the water column (Fairbanks et al., 1980, 1982; Erez and Honjo, 1981; Lohmann and Schweitzer, 1990; Kohfeld et al., 1996), and live at different times of the year (Deuser et al., 1981; Deuser and Ross, 1989). In foraminifer species that do not migrate vertically, individual shell chemistry could record shortterm variations in oceanic mixed layer chemistry, which would be sensitive to environmental perturbations, such as freshwater input from large precipitation events (e.g., Schiebel et al., 1995) or glacial meltwater flood events (Spero and Williams, 1990; Flower et al., 2004; Hill et al., 2006; Lopes and Mix, 2009). Bulk analyses and even individual shell analyses average such potential geochemical heterogeneity, thereby masking daily environmental information that may exist within the geochemistry of a single shell.

Data presented here demonstrate that oxygen isotope variations on daily timescales in a foraminifer shell could be resolved using SIMS analyses if the environmental changes were of sufficient magnitude to exceed the $\sim 0.3$ $1.1 \%$ precision obtained with a $3 \mu \mathrm{m} \mathrm{Cs}^{+}$beam spot. Such a signal could be derived from a $2-5^{\circ} \mathrm{C}$ change in habitat temperature that might be experienced during migration through a steep thermocline, or a large salinity change. Our experimental data also support interpretations of the SIMS data collected by Kozdon et al. (2011) from unaltered 

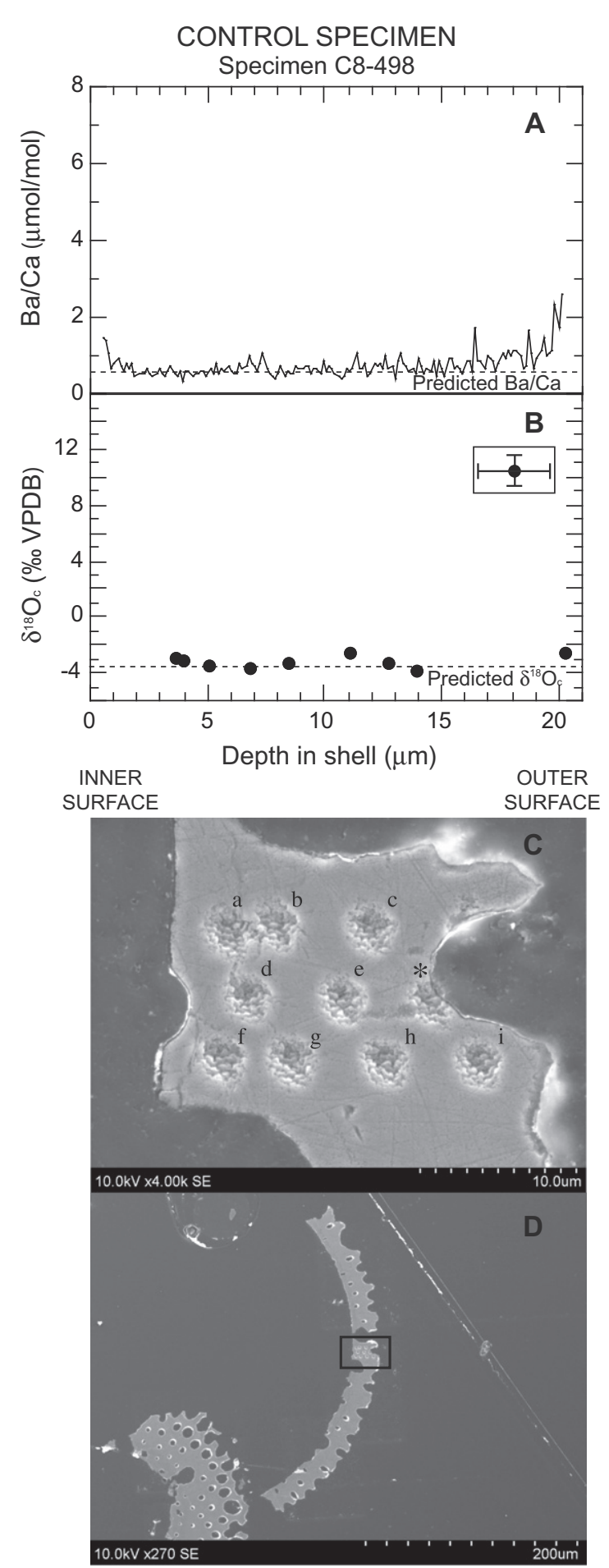

Fig. 2. Ba/Ca ratio depth profile (A), measured intrashell $\delta^{18} \mathrm{O}_{\mathrm{c}}(\mathrm{B})$ and SEM image of SIMS analysis pits $(\mathrm{C})$ and shell profile cross section (D) for a single $O$. universa (C8-498) cultured in synthetic seawater with constant $\mathrm{Ba} / \mathrm{Ca}$ and $\delta^{18} \mathrm{O}_{\mathrm{w}}$ during calcification (see text for culture methods). Horizontal dashed lines show predicted values for $\mathrm{Ba} / \mathrm{Ca}$ and $\delta^{18} \mathrm{O}_{\mathrm{c}}$ using empirical calibrations for $O$. universa (Bemis et al., 1998; Hönisch et al., 2011; Lea and Spero, 1994). Error bar in box in (B) shows \pm 2 SD on individual spot measurements (vertical) and spatial error of $3 \mu \mathrm{m}$ analysis spots (horizontal). Asterisk identifies analysis spot that is not included in data interpretation. calcite found in the basal portions of muricae of fossil Paleogene morozovellid foraminifers from deep-sea sediment cores. Ultimately, interpretation of a single SIMS $\delta^{18} \mathrm{O}_{\mathrm{c}}$ analysis is limited by the precision achievable on a single spot; if multiple spot analyses of homogeneous material are averaged, the standard error $(\mathrm{SD} /(\sqrt{ } n))$ of these analyses can more closely approach precision levels obtained from samples up to $10^{6}$ times larger using more common dual inlet or continuous flow phosphoric acid digestion techniques with isotope ratio mass spectrometry.

\subsection{Intrashell oxygen isotope variability in foraminifer shells}

Some species of modern planktic foraminifers add secondary layers of shell calcite during ontogenetic or reproductive (gametogenic) processes (Orr, 1967; Bé, 1980; Duplessy et al., 1981; Hamilton et al., 2008). Such gametogenic calcite and other secondary crusts are a part of the natural calcification process in foraminifera, but could be calcified at depths that differ from the 'normal' ontogenetic calcite in a shell. For instance, SIMS analyses of intrashell $\delta^{18} \mathrm{O}_{\mathrm{c}}$ conducted on an abundant high latitude species, $N$. pachyderma $\left(\sin\right.$.), showed a $\sim 3 \%$ o ${ }^{18} \mathrm{O}$ enrichment in its secondary crust over ontogenetic calcite (Kozdon et al., 2009). These data reveal the growth history of foraminifer shells from open ocean conditions and suggest that the crust is precipitated at a considerably greater depth in the water column than early ontogenetic shell calcite. The ability to analyze $\delta^{18} \mathrm{O}_{\mathrm{c}}$ values in different layers of shell calcite or individual chambers thus has the potential to unlock additional environmental and ecological information in species from oceanographic environments with a strong halocline or thermocline.

Temperature and light exposure experiments conducted on $O$. universa have shown that the $\delta^{18} \mathrm{O}_{\mathrm{c}}$ of sphere calcite is a function of both temperature and symbiont photosynthetic activity (Bemis et al., 1998). Data indicate that shells grown on a $12 \mathrm{~h}: 12 \mathrm{~h}$ light:dark cycle at constant temperature and $\delta^{18} \mathrm{O}_{\mathrm{w}}$ are depleted in ${ }^{18} \mathrm{O}$ by $\sim 0.3 \%$ relative to specimens grown continuously in the dark (Spero et al., 1997). The depletion is thought to be due to an increase in $\mathrm{pH}$ (and/or $\left[\mathrm{CO}_{3}{ }^{2-}\right]$ ) in the microenvironment surrounding the shell during the daylight hours when symbiont photosynthesis is at a maximum (Spero et al., 1997; Rink et al., 1998). Because $O$. universa precipitates $\sim 66 \%$ of its shell during the day (Spero and Parker, 1985; Lea et al., 1995), bands of day and night calcite should have discrete $\delta^{18} \mathrm{O}_{\mathrm{c}}$ signatures that differ by $\sim 1 \%$. This diurnal effect could contribute to intrashell $\delta^{18} \mathrm{O}_{\mathrm{c}}$ variability at the spatial resolution of our analyses. However, within the analytical precision of individual spot measurements $( \pm 0.3 \%$ to $1.1 \%, 2 \mathrm{SD}$ ) we are unable to resolve this predicted diurnal $\delta^{18} \mathrm{O}_{\mathrm{c}}$ oscillation in the specimen cultured continuously in ambient seawater.

\subsection{Geochemical labels in $O$. universa}

In a recent experiment, Gagnon et al. (2012) cultured $O$. universa and induced instantaneous changes in seawater cation chemistry by transferring specimens between culture 

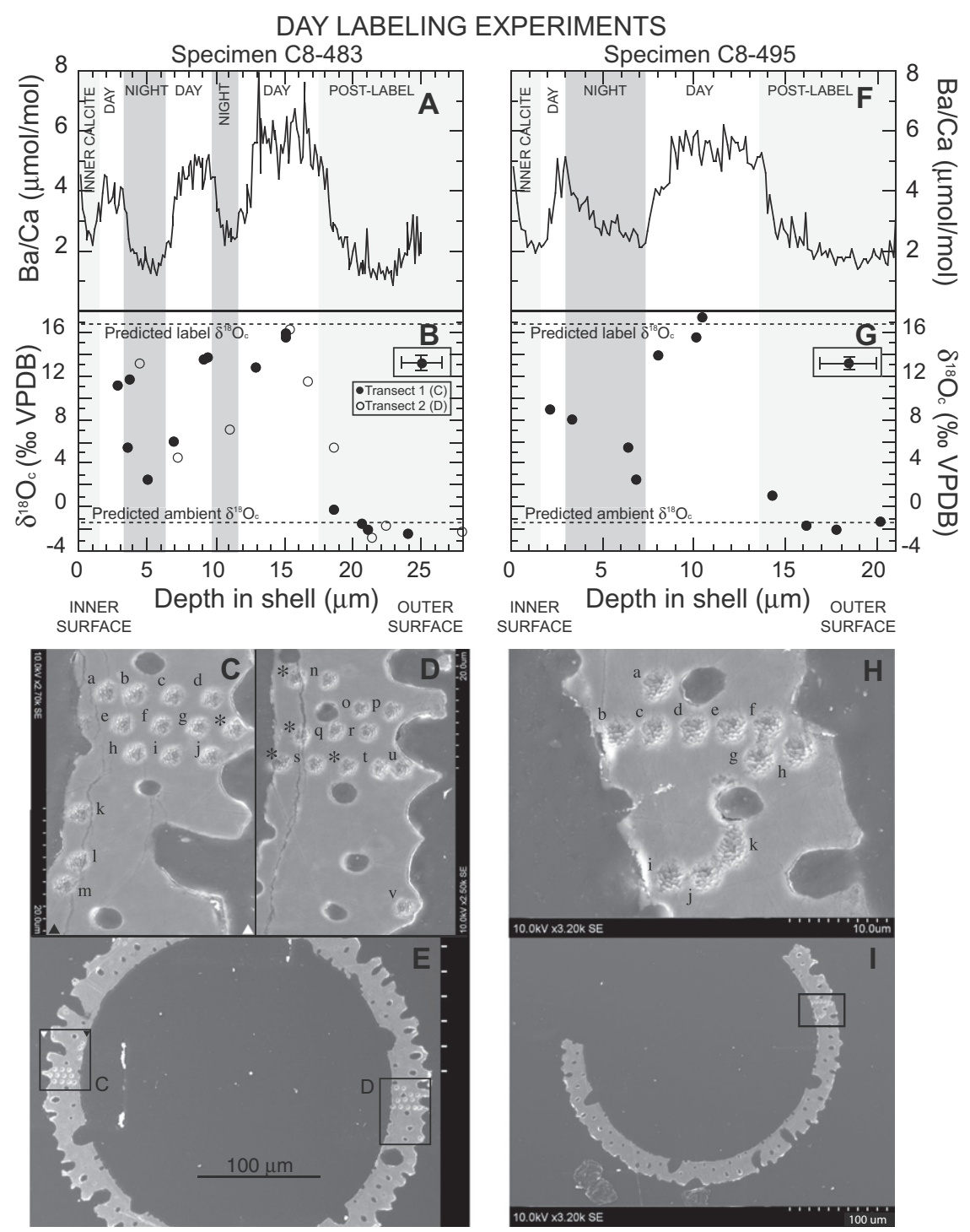

Fig. 3. $\mathrm{Ba} / \mathrm{Ca}$ ratio depth profiles $(\mathrm{A}, \mathrm{F})$, intrashell $\delta^{18} \mathrm{O}_{\mathrm{c}}(\mathrm{B}, \mathrm{G})$ and $\mathrm{SEM}$ images of SIMS analysis pits $(\mathrm{C}-\mathrm{E}$, $\mathrm{H}$, I) for two $O$. universa specimens (C8-483 and C8-495) cultured in day labeling experiments. Intrashell measurements of $\delta^{18} \mathrm{O}_{\mathrm{c}}$ in $(\mathrm{B})$ are from two separate transects across the direction of shell growth, shown in closed (C) and open (D) symbols, with \pm 2 SD shown by error bar in box (vertical) and spatial error range of $3 \mu \mathrm{m}$ analysis spots (horizontal). Shaded regions delineate $12 \mathrm{~h}$ night periods, commencing with the boundary between fullyresolved ambient shell calcite and the analytical mixing zone between ambient and labeled calcite. Inner calcite is indicated in areas where multiple narrow bands of calcite precipitated inside of the POM over multiple $12 \mathrm{~h}$ intervals, and individual layers cannot be resolved. Horizontal dashed lines show predicted values for $\delta^{18} \mathrm{O}_{\mathrm{c}}$ using empirical calibrations for calcification of $O$. universa (Bemis et al., 1998). SEM image $(\mathrm{C})$ is oriented so that inner and outer shell calcite correspond with $\delta^{18} \mathrm{O}_{\mathrm{c}}$ values in $(\mathrm{B})$. Shell thickness in the area used for LA-ICP-MS analysis in (A) differs slightly from shell thickness in (B)-(D). Asterisks identify analysis spots that were not used for data interpretation.

bottles with distinct isotopic labels. Their high-resolution nanoSIMS images demonstrate that changes in seawater chemistry are recorded within $<1 \mu \mathrm{m}$ of shell calcite in $O$. universa, and suggest that the full, equilibrium chemical signal of new seawater is expressed in shell calcite within 1-2 $\mathrm{h}$ for cations such as $\mathrm{Mg}^{2+}$ and $\mathrm{Ca}^{2+}$ (Gagnon et al., 2012). Because $\mathrm{Ba}^{2+}$ does not play a biological role in planktic foraminifer calcification (Lea and Spero, 1994; Hönisch et al., 2011), we infer that the behavior of $\mathrm{Ba}^{2+}$ is similar to that of other cations. Our $O$. universa specimens were cultured using the same protocol for instantaneous changes in sea- water chemistry, yet the LA-ICP-MS depth profiles of $\mathrm{Ba} / \mathrm{Ca}$ that we present here resolve spatial transitions in shell chemistry over 1-6 $\mu \mathrm{m}$ (Figs. 3A, F and 4A). The discrepancy in spatial resolution between nanoSIMS and LAICP-MS data suggests that analytical mixing occurs during LA-ICP-MS depth profiling. Such mixing could be due to signal smoothing from potential wall effects, ablation of a curved shell surface, and mixing of ablation products between successive laser pulses.

Measured intrashell $\delta^{18} \mathrm{O}_{\mathrm{c}}$ values in our cultured $O$. universa specimens primarily tend to fall between predicted 
NIGHT LABELING EXPERIMENT Specimen C8-728
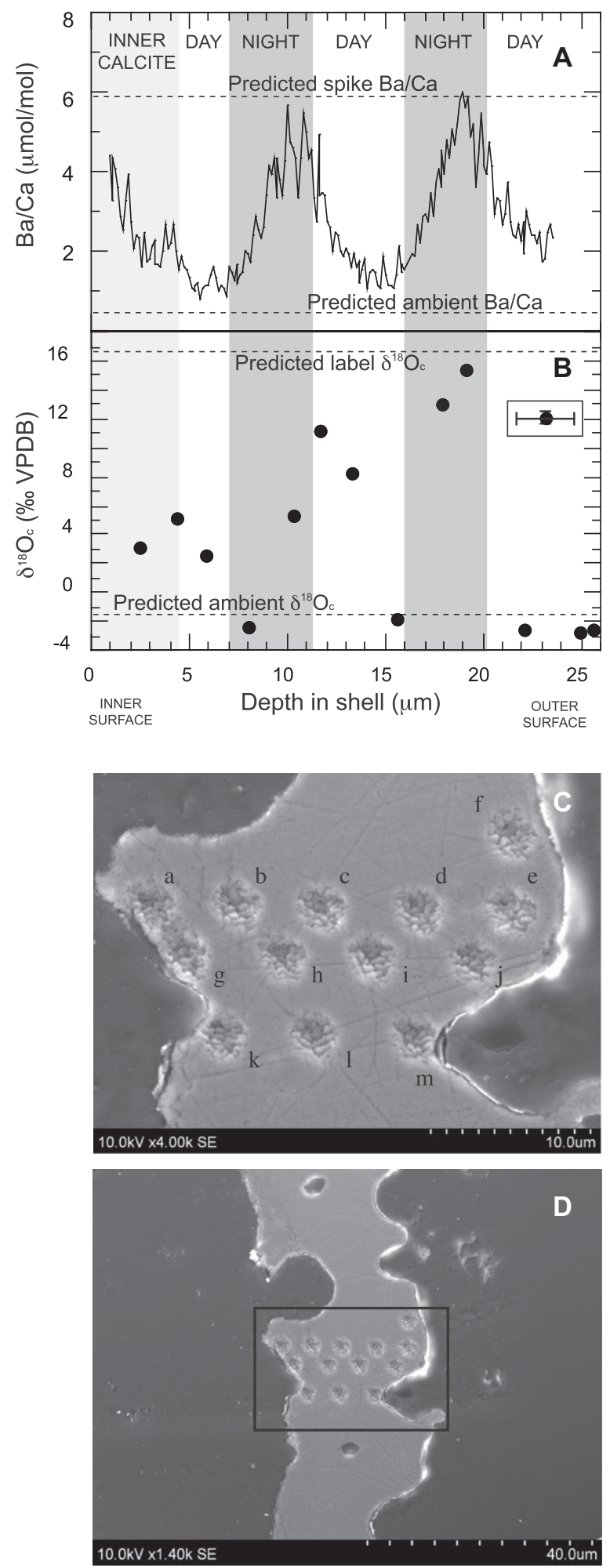

Fig. 4. Ba/Ca ratio depth profile (A), intrashell $\delta^{18} \mathrm{O}_{\mathrm{c}}(\mathrm{B})$ and SEM images of SIMS analysis pits $(\mathrm{C}$ and $\mathrm{D})$ for a single $O$. universa that was maintained in ambient seawater during $12 \mathrm{~h}$ day periods and transferred to labeled seawater during $12 \mathrm{~h}$ night periods. See Fig. 3 caption for detailed figure explanation. values for calcification in ambient or labeled seawater. These intermediate $\delta^{18} \mathrm{O}_{\mathrm{c}}$ values also represent a zone of analytical mixing in which a single $3 \mu \mathrm{m}$ ion microprobe spot simultaneously analyzes material from two bands of calcite with distinct geochemistries which are averaged into a single measurement. In contrast to LA-ICP-MS depth profiles, the analytical mixing zone for SIMS analyses is well-constrained because the diameter of the $3 \mu \mathrm{m}$ spot does not change with respect to position in the shell. This $3 \mu \mathrm{m}$ spatial resolution captures the full chemical transition from ${ }^{18} \mathrm{O}$-labeled calcite to calcite grown in ambient $\delta^{18} \mathrm{O}_{\mathrm{w}}$ (see Fig. 3B, 16-20 $\mu \mathrm{m}$; Fig. 4B, 19-22 $\mu \mathrm{m}$ ). Within the spatial resolution achievable for LA-ICP-MS and ion microprobe analyses, the agreement between the position of ${ }^{18} \mathrm{O}$ - and Ba-enriched bands and ambient bands of shell calcite is excellent. We observe no resolvable offset between the positions of these two tracers. Based on this spatial agreement, we propose that the flushing times for $\delta^{18} \mathrm{O}_{\mathrm{w}}$ and cations such as $\mathrm{Mg}^{2+}$ and $\mathrm{Ca}^{2+}$ have similar time constants of $1-2 \mathrm{~h}$.

\section{SUMMARY}

In this paper, we demonstrate the ability of the SIMS analytical technique to yield replicable in situ $\delta^{18} \mathrm{O}_{\mathrm{c}}$ analyses on biogenic shell calcite from cultured specimens of the planktic foraminifer $O$. universa using a $3 \mu \mathrm{m}$ spot. Within the standard deviation on any single spot measurement $( \pm 0.3 \%$ to $1.1 \%$, $2 \mathrm{SD})$, spot analyses placed entirely within bands of ambient or ${ }^{18} \mathrm{O}$-labeled calcite yield $\delta^{18} \mathrm{O}_{\mathrm{c}}$ values consistent with predictions from empirically-derived relationships for $O$. universa. Analytical mixing occurs during both LA-ICP-MS depth profiling and SIMS $\delta^{18} \mathrm{O}_{\mathrm{c}}$ analyses across multiple bands of shell calcite with different geochemistries. Ba and ${ }^{18} \mathrm{O}$ tracers appear to be incorporated into shell calcite with no measurable offset, and are cross-correlated within the spatial resolution of the analytical mixing zones for each technique. These findings suggest that cation and stable isotope tracers in seawater are synchronously recorded during shell calcification. The experimental results we present here support the application of intrashell $\delta^{18} \mathrm{O}_{\mathrm{c}}$ measurements in foraminiferal calcite to paleoceanographic questions.

With the demonstrated ability to measure shell calcite $\delta^{18} \mathrm{O}$ on timescales $<12 \mathrm{~h}$, it may now be possible to quantify daily or diurnal events in planktic foraminifer shell geochemistry from the fossil record. These results highlight the potential for SIMS analyses to extract paleoenvironmental information from fossil material that may open new approaches to reconstructing foraminifera paleoecology from extinct species or ultra-high resolution oceanographic events from the fossil record. In situ SIMS analyses also have the potential to investigate intrashell carbon isotope variation, to reconstruct seawater carbonate chemistry and carbon uptake dynamics as well as intrashell boron isotope values, thereby providing insight into both seawater paleo-pH and vital effects during biomineralization (Rollion-Bard and Erez, 2010). In combination with the new suite of high resolution LA-ICP-MS trace element techniques currently being used to study the fossil record, SIMS 
Table 3

Measured $\delta^{18} \mathrm{O}_{\mathrm{w}}$ and predicted $O$. universa shell $\delta^{18} \mathrm{O}_{\mathrm{c}}$.

\begin{tabular}{lllll}
\hline Water sample & Measured $\delta^{18} \mathrm{O}_{\mathrm{w}}(\%$ VSMOW $)$ & Precision $( \pm 1 \mathrm{SD})$ & $\#$ of replicates analyzed & Predicted shell $\delta^{18} \mathrm{O}_{\mathrm{c}}(\% \text { o } \mathrm{VPDB})^{\mathrm{a}}$ \\
\hline Synthetic & -1.54 & 0.05 & 3 & -3.29 \\
Ambient & -0.40 & 0.05 & 12 & -2.15 \\
Spike & +18.65 & 0.03 & 3 & +16.90 \\
\hline
\end{tabular}

${ }^{\text {a }}$ O. universa $\delta^{18} \mathrm{O}_{\text {calcite }}$ predicted using the relationship for high-intensity light of Bemis et al. (1998).

analyses provides a powerful tool for paleoclimate reconstruction that has the potential to extract novel information from the geologic record that was not previously possible.

\section{ACKNOWLEDGMENTS}

We gratefully acknowledge the field assistance of A. Russell, K. Allen, S. Doo, K. James, and the staff of the Wrigley Marine Science Center. We also thank N. Kita, J. Kern, and S. Roeske for analytical support and G. Nash, B. Hess, B. Joy, and D.C. Kelly for assistance with sample preparation. This research was supported by NSF Grants OCE-0550703 (H.J.S.), OCE-0751764 (B.H.), and Los Alamos National Laboratory award IGPP:09RFP-008 (C.I.M. and H.J.S.). WiscSIMS is partially supported by NSF-EAR $(0319230,0744079,1053466)$.

\section{APPENDIX A. SUPPLEMENTARY DATA}

Supplementary data associated with this article can be found, in the online version, at http://dx.doi.org/10.1016/ j.gca.2012.12.046.

\section{REFERENCES}

Allison N. and Austin W. E. N. (2003) The potential of ion microprobe analysis in detecting geochemical variations across individual foraminifera tests. Geochem. Geophys. Geosyst. 4. http://dx.doi.org/10.1029/2002GC000430.

Anand P. and Elderfield H. (2005) Variability of $\mathrm{Mg} / \mathrm{Ca}$ and $\mathrm{Sr} / \mathrm{Ca}$ between and within the planktonic foraminifers Globigerina bulloides and Globorotalia truncatulinoides. Geochem. Geophys. Geosyst. 6. http://dx.doi.org/10.1029/2004GC000811.

Bé A. W. H. (1980) Gametogenic calcification in a spinose planktonic foraminifer, Globigerinoides sacculifer (Brady). Mar. Micropaleontol. 5, 283-310. http://dx.doi.org/10.1016/ 0377-8398(80)90014-6.

Bemis B. E., Spero H. J., Bijma J. and Lea D. W. (1998) Reevaluation of the oxygen isotopic composition of planktonic foraminifera: experimental results and revised paleotemperature equations. Paleoceanography 13, 150-160.

Bice K. L., Layne G. D. and Dahl K. (2005) Application of secondary ion mass spectrometry to the determination of $\mathrm{Mg}$ / $\mathrm{Ca}$ in rare, delicate, or altered planktonic foraminifera: examples from the Holocene, Paleogene, and Cretaceous. Geochem. Geophys. Geosyst. 6. http://dx.doi.org/10.1029/2005GC000974.

Billups K. and Spero H. J. (1996) Reconstructing the stable isotope geochemistry and paleotemperatures of the equatorial Atlantic during the last 150,000 years: results from individual foraminifera. Paleoceanography 11, 217-238.

Caron D. A., Faber W. W. and Bé A. W. H. (1987) Growth of the spinose planktonic foraminifer Orbulina universa in laboratory culture and the effect of temperature on life processes. J. Mar.
Biol. Assoc. UK 67, 343-358. http://dx.doi.org/10.1017/ S0025315400026655.

Coplen T. B., Kendall C. and Hopple J. (1983) Comparison of stable isotope reference samples. Nature 302, 236-238.

Curry W. B. and Marchitto T. M. (2008) A secondary ionization mass spectrometry calibration of Cibicidoides pachyderma $\mathrm{Mg} /$ $\mathrm{Ca}$ with temperature. Geochem. Geophys. Geosyst. 9, Q04009. http://dx.doi.org/10.1029/2007GC001620.

Deuser W. G. and Ross E. H. (1989) Seasonally abundant planktonic foraminifera of the Sargasso Sea - succession, deep water fluxes, isotopic compositions, and paleoceanographic implications. J. Foramin. Res. 19, 268-293.

Deuser W. G., Ross E. H., Hemleben C. and Spindler M. (1981) Seasonal changes in species composition, numbers, mass, size, and isotopic composition of planktonic foraminifera settling into the deep Sargasso Sea. Palaeogeogr. Palaeoclimatol. Palaeoecol. 33, 103-127. http://dx.doi.org/10.1016/00310182(81)90034-1.

Duplessy J. C., Blanc P. L. and Bé A. W. H. (1981) Oxygen-18 enrichment of planktonic foraminifera due to gametogenic calcification below the euphotic zone. Science 213, 1247-1250.

Eggins S., De Deckker P. and Marshall J. (2003) Mg/Ca variation in planktonic foraminifera tests: implications for reconstructing palaeo-seawater temperature and habitat migration. Earth Planet. Sci. Lett. 212, 291-306. http://dx.doi.org/10.1016/ s0012-821x(03)00283-8.

Eggins S. M., Sadekov A. and De Deckker P. (2004) Modulation and daily banding of $\mathrm{Mg} / \mathrm{Ca}$ in Orbulina universa tests by symbiont photosynthesis and respiration: a complication for seawater thermometry? Earth Planet. Sci. Lett. 225, 411-419. http://dx.doi.org/10.1016/j.epsl.2004.06.019.

Emiliani C. (1955) Pleistocene temperatures. J. Geol. 63, 538-578.

Epstein S., Buchsbaum R., Lowenstam H. A. and Urey H. C. (1953) Revised carbonate-water isotopic temperature scale. Geol. Soc. Am. Bull. 64, 1315-1325.

Erez J. and Honjo S. (1981) Comparison of isotopic composition of planktonic foraminifera in plankton tows, sediment traps and sediments. Palaeogeogr. Palaeoclimatol. Palaeoecol. 33, 129156. http://dx.doi.org/10.1016/0031-0182(81)90035-3.

Fairbanks R. G., Sverdlove M., Free R., Wiebe P. H. and Bé A. W. H. (1982) Vertical distribution and isotopic fractionation of living planktonic foraminifera from the Panama Basin. Nature 298, 841-844.

Fairbanks R. G., Wiebe P. H. and Bé A. W. H. (1980) Vertical distribution and isotopic composition of living planktonic foraminifera in the western North Atlantic. Science 207, 61-63.

Flower B. P., Hastings D. W., Hill H. W. and Quinn T. M. (2004) Phasing of deglacial warming and Laurentide Ice Sheet meltwater in the Gulf of Mexico. Geology 32, 597-600. http:// dx.doi.org/10.1130/G20604.1.

Gagnon A. C., DeYoreo J. J., DePaolo D. J., Spero H. J., Russell A. D. and Giuffre A. (2012) $\mathrm{Me} / \mathrm{Ca}$ proxies and foram biomineralization: the role of cation transport. Mineral. Mag. 76, 1730 . 
Ganssen G. M., Peeters F. J. C., Metcalfe B., Anand P., Jung S. J. A., Kroon D. and Brummer G. J. A. (2011) Quantifying sea surface temperature ranges of the Arabian Sea for the past 20,000 years. Climate Past 7, 1337-1349. http://dx.doi.org/ 10.5194/cp-7-1337-2011.

GeoReM Database, 2009. Available from: <http://georem.mpchmainz.gwdg.de/>.

Hamilton C. P., Spero H. J., Bijma J. and Lea D. W. (2008) Geochemical investigation of gametogenic calcite addition in the planktonic foraminifera Orbulina universa. Mar. Micropaleontol. 68, 256-267. http://dx.doi.org/10.1016/j.marmicro. 2008.04.003.

Hathorne E. C., Alard O., James R. H. and Rogers N. W. (2003) Determination of intratest variability of trace elements in foraminifera by laser ablation inductively coupled plasma-mass spectrometry. Geochem. Geophys. Geosyst. 4, 8408. http:// dx.doi.org/10.1029/2003gc000539.

Hathorne E. C., James R. H. and Lampitt R. S. (2009) Environmental versus biomineralization controls on the intratest variation in the trace element composition of the planktonic foraminifera G. inflata and G. scitula. Paleoceanography 24, PA4204. http://dx.doi.org/10.1029/2009pa001742.

Hill H. W., Flower B. P., Quinn T. M., Hollander D. J. and Guilderson T. P. (2006) Laurentide Ice Sheet meltwater and abrupt climate change during the last glaciation. Paleoceanography 21, PA1006. http://dx.doi.org/10.1029/2005PA001186.

Hönisch B., Allen K. A., Russell A. D., Eggins S. M., Bijma J., Spero H. J., Lea D. W. and Yu J. (2011) Planktic foraminifers as recorders of seawater $\mathrm{Ba} / \mathrm{Ca}$. Mar. Micropaleontol. 79, 5257. http://dx.doi.org/10.1016/j.marmicro.2011.01.003.

Killingley J. S., Johnson R. F. and Berger W. H. (1981) Oxygen and carbon isotopes of individual shells of planktonic foraminifera from Ontong Java Plateau, Equatorial Pacific. Palaeogeogr. Palaeoclimatol. Palaeoecol. 33, 193-204. http:// dx.doi.org/10.1016/0031-0182(81)90038-9.

Kohfeld K. E., Fairbanks R. G., Smith S. L. and Walsh I. D. (1996) Neogloboquadrina pachyderma (sinistral coiling) as paleoceanographic tracers in polar oceans: evidence from northeast water Polynya plankton tows, sediment traps, and surface sediments. Paleoceanography 11, 679-699.

Koutavas A., deMenocal P. B., Olive G. C. and Lynch-Stieglitz J. (2006) Mid-Holocene El Niño-Southern Oscillation (ENSO) attenuation revealed by individual foraminifera in eastern tropical Pacific sediments. Geology 34, 993-996.

Kozdon R., Kelly D. C., Kita N. T., Fournelle J. H. and Valley J. W. (2011) Planktonic foraminiferal oxygen isotope analysis by ion microprobe technique suggests warm tropical sea surface temperatures during the Early Paleogene. Paleoceanography 26, PA3206. http://dx.doi.org/10.1029/2010pa002056.

Kozdon R., Ushikubo T., Kita N. T., Spicuzza M. and Valley J. W. (2009) Intratest oxygen isotope variability in the planktonic foraminifer $N$. pachyderma: real vs. apparent vital effects by ion microprobe. Chem. Geol. 258, 327-337.

Kunioka D., Shirai K., Takahata N., Sano Y., Toyofuku T. and Ujiie Y. (2006) Microdistribution of $\mathrm{Mg} / \mathrm{Ca}, \mathrm{Sr} / \mathrm{Ca}$, and $\mathrm{Ba} / \mathrm{Ca}$ ratios in Pulleniatina obliquiloculata test by using a NanoSIMS: implication for the vital effect mechanism. Geochem. Geophys. Geosyst. 7. http://dx.doi.org/10.1029/2006GC001280.

Lea D. W., Martin P. A., Chan D. A. and Spero H. J. (1995) Calcium uptake and calcification rate in the planktonic foraminifer Orbulina universa. J. Foramin. Res. 25, 14-23. http:// dx.doi.org/10.2113/gsjfr.25.1.14.

Lea D. W., Mashiotta T. A. and Spero H. J. (1999) Controls on magnesium and strontium uptake in planktonic foraminifera determined by live culturing. Geochim. Cosmochim. Acta 63, 2369-2379.
Lea D. W., Pak D. K. and Spero H. J. (2000) Climate impact of late quaternary equatorial pacific sea surface temperature variations. Science 289, 1719-1724. http://dx.doi.org/10.1126/ science.289.5485.1719.

Lea D. W. and Spero H. J. (1992) Experimental determination of barium uptake in shells of the planktonic foraminifera Orbulina universa at $22^{\circ} \mathrm{C}$. Geochim. Cosmochim. Acta 56, 2673-2680.

Lea D. W. and Spero H. J. (1994) Assessing the reliability of paleochemical tracers: barium uptake in the shells of planktonic foraminifera. Paleoceanography 9, 445-452.

Leduc G., Vidal L., Cartapanis O. and Bard E. (2009) Modes of eastern equatorial Pacific thermocline variability: implications for ENSO dynamics over the last glacial period. Paleoceanography 24, PA3202. http://dx.doi.org/10.1029/ 2008 pa001701.

Lohmann G. P. and Schweitzer P. N. (1990) Globorotalia truncatulinoides: growth and chemistry as probes of the past thermocline: 1. Shell size. Paleoceanography 5, 55-75. http:// dx.doi.org/10.1029/PA005i001p00055.

Lopes C. and Mix A. C. (2009) Pleistocene megafloods in the northeast Pacific. Geology 37, 79-82. http://dx.doi.org/10.1130/ G25025A.1.

Olson I. C., Kozdon R., Valley J. W. and Gilbert P. (2012) Mollusk shell nacre ultrastructure correlates with environmental temperature and pressure. J. Am. Chem. Soc. 134, 7351-7358. http://dx.doi.org/10.1021/ja210808s.

Orland I. J., Bar-Matthews M., Ayalon A., Matthews A., Kozdon R., Ushikubo T. and Valley J. W. (2012) Seasonal resolution of Eastern Mediterranean climate change since $34 \mathrm{ka}$ from a Soreq Cave speleothem. Geochim. Cosmochim. Acta 89, 240-255. http://dx.doi.org/10.1016/j.gca.2012.04.035.

Orland I. J., Bar-Matthews M., Kita N. T., Ayalon A., Matthews A. and Valley J. W. (2009) Climate deterioration in the Eastern Mediterranean as revealed by ion microprobe analysis of a speleothem that grew from 2.2 to $0.9 \mathrm{ka}$ in Soreq Cave, Israel. Quatern. Res. 71, 27-35. http://dx.doi.org/10.1016/j.yqres.2008. 08.005 .

Orr W. N. (1967) Secondary calcification in the foraminiferal genus Globorotalia. Science 157, 1554-1555. http://dx.doi.org/ 10.1126/science.157.3796.1554.

Page F. Z., Ushikubo T., Kita N. T., Riciputi L. R. and Valley J. W. (2007) High-precision oxygen isotope analysis of picogram samples reveals $2 \mu \mathrm{m}$ gradients and slow diffusion in zircon. Am. Mineral. 92, 1772-1775. http://dx.doi.org/10.2138/ am.2007.2697.

Pena L. D., Cacho I., Calvo E., Pelejero C., Eggins S. and Sadekov A. (2008) Characterization of contaminant phases in foraminifera carbonates by electron microprobe mapping. Geochem. Geophys. Geosyst. 9, Q07012. http://dx.doi.org/10.1029/ 2008GC002018.

Pena L. D., Calvo E., Cacho I., Eggins S. and Pelejero C. (2005) Identification and removal of $\mathrm{Mn}-\mathrm{Mg}$-rich contaminant phases on foraminiferal tests: implications for $\mathrm{Mg} / \mathrm{Ca}$ past temperature reconstructions. Geochem. Geophys. Geosyst. 6, Q09P02. http:// dx.doi.org/10.1029/2005GC000930.

Reichart G. J., Jorissen F., Anschutz P. and Mason P. R. D. (2003) Single foraminiferal test chemistry records the marine environment. Geology 31, 355-358.

Rink S., Kühl M., Bijma J. and Spero H. J. (1998) Microsensor studies of photosynthesis and respiration in the symbiotic foraminifer Orbulina universa. Mar. Biol. 131, 583-595.

Rollion-Bard C. and Erez J. (2010) Intra-shell boron isotope ratios in the symbiont-bearing benthic foraminiferan Amphistegina lobifera: implications for $\delta^{11} \mathrm{~B}$ vital effects and paleo-pH reconstructions. Geochim. Cosmochim. Acta 74, 1530-1536. http://dx.doi.org/10.1016/j.gca.2009.11.017. 
Rollion-Bard C., Erez J. and Zilberman T. (2008) Intra-shell oxygen isotope ratios in the benthic foraminifera genus Amphistegina and the influence of seawater carbonate chemistry and temperature on this ratio. Geochim. Cosmochim. Acta 72, 6006-6014.

Russell A. D., Hönisch B., Spero H. J. and Lea D. W. (2004) Effects of seawater carbonate ion concentration and temperature on shell $\mathrm{U}, \mathrm{Mg}$, and $\mathrm{Sr}$ in cultured planktonic foraminifera. Geochim. Cosmochim. Acta 68, 4347-4361.

Sadekov A., Eggins S. M., De Deckker P. and Kroon D. (2008) Uncertainties in seawater thermometry deriving from intratest and intertest $\mathrm{Mg} / \mathrm{Ca}$ variability in Globigerinoides ruber. Paleoceanography 23, PA1215. http://dx.doi.org/10.1029/2007 pa001452.

Sadekov A., Eggins S. M., De Deckker P., Ninnemann U., Kuhnt W. and Bassinot F. (2009) Surface and subsurface seawater temperature reconstruction using $\mathrm{Mg} / \mathrm{Ca}$ microanalysis of planktonic foraminifera Globigerinoides ruber, Globigerinoides sacculifer, and Pulleniatina obliquiloculata. Paleoceanography 24, PA3201. http://dx.doi.org/10.1029/2008pa001664.

Sadekov A. Y., Eggins S. M. and De Deckker P. (2005) Characterization of $\mathrm{Mg} / \mathrm{Ca}$ distributions in planktonic foraminifera species by electron microprobe mapping. Geochem. Geophys. Geosyst. 6, Q12P06. http://dx.doi.org/10.1029/2005gc000973.

Sadekov A. Y., Eggins S. M., Klinkhammer G. P. and Rosenthal Y. (2010) Effects of seafloor and laboratory dissolution on the $\mathrm{Mg} / \mathrm{Ca}$ composition of Globigerinoides sacculifer and Orbulina universa tests - a laser ablation ICPMS microanalysis perspective. Earth Planet. Sci. Lett. 292, 312-324.

Schiebel R., Hiller B. and Hemleben C. (1995) Impacts of storms on recent planktic foraminiferal test production and $\mathrm{CaCO}_{3}$ flux in the North Atlantic at $47^{\circ} \mathrm{N}, 20^{\circ} \mathrm{W}$ (JGOFS). Mar. Micropaleontol. 26, 115-129. http://dx.doi.org/10.1016/03778398(95)00035-6.

Schiffelbein P. and Hills S. (1984) Direct assessment of stable isotope variability in planktonic foraminifera populations. Palaeogeogr. Palaeoclimatol. Palaeoecol. 48, 197-213.

Shirai K., Otake T., Kuroki M., Ushikubo T., Kita N. T., Amano Y., Tsukamoto K. and Valley J. W. (2010) Eel larvae may hatch in the surface layer near the West Mariana Ridge: ion microprobe delta $\mathrm{O}-18$ analysis with $7 \mu \mathrm{m}$ spatial resolution in glass eel otoliths. Geochim. Cosmochim. Acta 74, A955.
Slowey N. C. and Curry W. B. (1995) Glacial-interglacial differences in circulation and carbon cycling within the upper western north-Atlantic. Paleoceanography 10, 715732.

Spero H. J. (1988) Ultrastructural examination of chamber morphogenesis and biomineralization in the planktonic foraminifer Orbulina universa. Mar. Biol. 99, 9-20.

Spero H. J., Bijma J., Lea D. W. and Bemis B. E. (1997) Effect of seawater carbonate concentration on foraminiferal carbon and oxygen isotopes. Nature 390, 497-500.

Spero H. J., Eggins S. M., Russell A. D., Vetter L. and Hönisch B. (2012) Timing and mechanism for intratest $\mathrm{Mg} / \mathrm{Ca}$ variability in living planktic foraminifera. Mineral. Mag. 76, 2399.

Spero H. J. and Parker S. L. (1985) Photosynthesis in the symbiotic planktonic foraminifer Orbulina universa, and its potential contribution to oceanic primary productivity. J. Foramin. Res. 15, 273-281. http://dx.doi.org/10.2113/gsjfr.15.4.273.

Spero H. J. and Williams D. F. (1988) Extracting environmental information from planktonic foraminiferal [delta]13C data. Nature 335, 717-719.

Spero H. J. and Williams D. F. (1990) Evidence for seasonal lowsalinity surface waters in the Gulf of Mexico over the last 16,000 years. Paleoceanography 5, 963-975.

Stap L., Lourens L., van Dijk A., Schouten S. and Thomas E. (2010) Coherent pattern and timing of the carbon isotope excursion and warming during Eocene Thermal Maximum 2 as recorded in planktic and benthic foraminifera. Geochem. Geophys. Geosyst. 11. http://dx.doi.org/10.1029/2010gc003097.

Valley J. W. (2003) Oxygen isotopes in zircon. Rev Mineral Geochem 53, 343-365.

Weidel B. C., Ushikubo T., Carpenter S. R., Kita N. T., Cole J. J., Kitchell J. F., Pace M. L. and Valley J. W. (2007) Diary of a bluegill (Lepomis macrochirus): daily $\delta^{13} \mathrm{C}$ and $\delta^{18} \mathrm{O}$ records in otoliths by ion microprobe. Can. J. Fish. Aquat. Sci. 64, 16411645. http://dx.doi.org/10.1139/f07-157.

Weldeab S., Lea D. W., Schneider R. R. and Andersen N. (2007) 155,000 years of West African monsoon and ocean thermal evolution. Science 316, 1303-1307. http://dx.doi.org/10.1126/ science. 1140461 . 